\title{
Erratum to: Effects of adriamycin and candesartan on the collagen and elastin of the aorta in rats
}

\author{
Jae-Sun Uhm ${ }^{1 \dagger}$, Woo-Baek Chung ${ }^{2 \dagger}$, Jung-Sook Yoon ${ }^{3}$, Yong-Seog $\mathrm{Oh}^{2}$ and Ho-Joong Youn ${ }^{2,4^{*}}$
}

After publication of the article [1] it was discovered that a citation error had occurred, resulting in different citation numbers in the PDF and HTML files. The correct citation of 20:8 has now been updated in all versions of the manuscript. We apologise for any inconvenience caused by this error.

\footnotetext{
Author details

'Department of Cardiology, Severance Hospital, Yonsei University College of Medicine, Seoul, Korea. ${ }^{2}$ Department of Cardiology, Catholic University of Korea College of Medicine, Seoul, Korea. ${ }^{3}$ Clinical Research Center, Yeouido St Mary's Hospital, Seoul, Korea. ${ }^{4}$ Department of Cardiology, Cardiovascular Center, Seoul St. Mary's Hospital, 222 Banpo-daero, Seocho-gu, Seoul

137-701, Korea.
}

Received: 30 April 2015 Accepted: 6 May 2015

Published online: 01 July 2015

\section{Reference}

1. Uhm J-S, Chung W-B, Yoon J-S, Oh Y-S, Youn H-J. Effects of adriamycin and candesartan on the collagen and elastin of the aorta in rats. Clin Hypertens. 2014:20:8.

\footnotetext{
*Correspondence: younhj@catholic.ac.kr

${ }^{\dagger}$ Equal contributors

2Department of Cardiology, Catholic University of Korea College of Medicine, Seoul, Korea

${ }^{4}$ Department of Cardiology, Cardiovascular Center, Seoul St. Mary's Hospital, 222 Banpo-daero, Seocho-gu, Seoul 137-701, Korea
}

\author{
Submit your next manuscript to BioMed Central \\ and take full advantage of: \\ - Convenient online submission \\ - Thorough peer review \\ - No space constraints or color figure charges \\ - Immediate publication on acceptance \\ - Inclusion in PubMed, CAS, Scopus and Google Scholar \\ - Research which is freely available for redistribution
}

Submit your manuscript at www.biomedcentral.com/submit

( Biomed Central

\section{Biomed Central}

